\title{
Peningkatan Penguasaan Konsep Energi Melalui Implementasi Pendekatan Keterampilan Proses
}

\author{
Masrah \\ SDN 004/V Kuala Tungkal, Kab. Tanjung Jabung Barat, Provinsi Jambi \\ email: masrah601@gmail.com
}

\begin{abstract}
The process skills approach is the management of learning activities by getting students actively involved. It is expected to be able to overcome problems that occur in students, namely difficulties in understanding the concept of learning science. This research is a class action research in two cycles. The study was conducted at SDN 004 / V Kuala Tungkal in class $I V-B$ with a total of 32 students. To test the successful implementation of the process skills approach 10 questions were used for each cycle. Data obtained from test results, observations, and interviews with students. The results showed the average student score increased from 40.63 in pre-cycle to 50.63 in cycle I and 66.88 in cycle II. Based on interviews conducted, students feel better when learning with a process skills approach because they feel that's more fun.
\end{abstract}

Keywords: Conceptual understanding, energy, procces skills approach.

\begin{abstract}
Abstrak
Pendekatan keterampilan proses merupakan pengelolaan kegiatan pembelajaran dengan mengupayakan siswa terlibat secara aktif. Hal tersebut diharapkan dapat mengatasi permasalahan yang terjadi pada siswa, yakni kesulitan dalam memahami konsep pembelajaran IPA. Penelitian ini merupakan penelitian tindakan kelas dalam dua siklus. Penelitian di lakukan di SDN 004/V Kuala Tungkal pada kelas IV-B dengan jumlah siswa sebanyak 32 siswa. Untuk menguji keberhasilan implementasi pendekatan keterampilan proses digunakan 10 soal untuk tiap siklus. Data diperoleh dari hasil tes, observasi, dan wawancara pada siswa. Hasil penelitian menunjukkan rata-rata skor siswa meningkat dari 40,63 pada pra siklus menjadi 50,63 pada siklus I dan 66,88 pada siklus II. Berdasarkan wawancara yang dilakukan, siswa merasa lebih baik jika belajar dengan pendekatan keterampilan proses karena tidak merasa mudah bosan.
\end{abstract}

Kata Kunci: Penguasaan konsep, energi, pendekatan keterampilan proses. 


\section{PENDAHULUAN}

Ilmu Pengetahuan Alam (IPA) merupakan disiplin ilmu yang memiliki kedudukan menjelaskan bermacam fenomena alam yang disusun secara sistematis dengan didasari fakta yang empiris pada hasil percobaan dan observasi yang dilakukan oleh manusia (Asrini, Ratman, \& Laganing, 2016). IPA merupakan pelajaran yang penting dan sesuai dengan karakteristik siswa SD, karena IPA dapat mengungkap pengetahuan alam semesta yang berkaitan dengan lingkungan sekitarnya. Dengan belajar IPA, dapat meningkatkan kemampuan siswa ke arah sikap dan kemampuan yang baik dan berguna bagi lingkungan (Erowati, 2015; Samatowa, 2006).

Tujuan umum pembelajaran adalah agar siswa mampu membangun konsep dengan kokoh dan komprehensif. Pemahaman konsep yang baik berguna bagi siswa untuk menjelaskan bermacam fenomena fisis dan memecahkan persoalan terkait (Docktor, Strand, Mestre, \& Ross, 2015; Rivaldo, Taqwa, \& Taurusi, 2018; Ryan, Frodermann, Heller, Hsu, \& Mason, 2016; Taqwa \& Faizah,

Pembelajaran akan lebih bermakna jika melibatkan siswa secara aktif dalam mengkonstruksi pengetahuannya. Salah satu upaya yang dapat dilakukan agar siswa terlibat secara aktif dalam pembelajaran adalah dengan menerapkan pendekatan keterampilan proses. Menurut Semiawan (1989) pendekatan keterampilan proses adalah pendekatan belajar yang mengembangkan keterampilan memproseskan perolehan, anak akan mampu menemukan dan mengembangkan sendiri fakta dan konsep, selain itu menumbuhkan dan 2016a, 2016b; Taqwa \& Pilendia, 2018; Taqwa \& Rivaldo, 2019).

Namun pada kenyataannya pembelajaran IPA di SD belum sesuai harapan. Pembelajaran lebih diorientasikan pada metode ceramah, bukan melalui pendekatan saintifik yang seharusnya. Guru lebih sering melakukan pembelajaran dengan metode konvensional (Agustinawati, 2014; Asrini et al., 2016; Hasan, 2017; Husna \& Pinem, 2011; Nuraisah, Irawati, \& Hanifah, 2016; Saparwadi, 2016).

Salah satu penyebab dari hal tersebut adalah ditemukan bahwa kebutuhan sekolah diantaranya adalah materi tercetak yang berorientasi pada pendekatan keterampilan proses (Nur,dkk (2002) dalam Roosyanti (2017)).

Berdasarkan hasil penelitian Sayekti \& Kinasih (2017) bahwa guru selama ini masih menitikberatkan pada aspek kognitif dan keaktifan peserta didik, dan beberapa hambatan yang ditemukan dalam pelaksanaan penanaman KPS yaitu kurangnya pemahaman guru terhadap KPS dan keterampilan guru dalam mengelola kelas.

mengembangkan sikap dan nilai yang diharapkan.

Pentingnya implementasi pendekatan keterampilan proses dalam pembelajaran ini didasari pada pendapat Semiawan (1992) yakni, (1) melihat pesatnya perkembangan ilmu pada era sekarang tidak mungkin jika siswa diajarkan seluruh fakta dan konsep, sehingga mereka perlu diberi bekal keterampilan proses untuk mereka gunakan dalam mengonstruksi pengetahuan mereka secara mandiri; (2) menurut ahli psikologi, siswa akan lebih baik dalam memahami konsepkonsep yang bersifat abstrak jika 
diajarkan dengan membawa contohcontoh yang kongkret; (3) sebenarnya guru tidak bertugas untuk memberikan pengetahuan pada siswa melalui proses 'transfer' pengetahuan, melainkan menciptakan suasana yang mampu menggiring siswa untuk mengamati, bertanya, bereksperimen, dan menemukan konsep serta fakta secara mandiri; (4) ilmu yang telah dibangun tidak mutlak benar, sehingga siswa harus dilatih agar mampu berpikir dan bertindak kreatif; dan (5) dalam pelaksanaan pembelajaran, pengembangan konsep siswa tidak dapat dilepaskan dari pengembangan sikap, termasuk sikap dalam bersosial.

Hal ini sesuai dengan teori Piaget yang mengemukakan bahwa tingkat perkembangan psikologi siswa SD masih berada pada tahap operasional konkrit. Anak-anak mudah memahami konsep-konsep yang abstrak apabila disertai contoh-contoh konkrit dalam mempraktekkan sendiri upaya penemuan-penemuan konsep melalui benda nyata (Winataputra (1993) dalam Acesta (2014)).

Siswa akan melaksanakan delapan tahapan keterampilan proses, yaitu mengamati, menggolongkan (mengklasifikasi). Menginterferensi (menafsirkan), meramalkan, menerapkan, merencanakan, dan mengkomunikasikan (Najiah, 2019).

Berikut ini merupakan langkahlangkah melaksanakan keterampilan proses (Semiawan (1989)) :

1) Pendahuluan atau pemanasan.

a) Pengulasan atau pengumpulan bahan yang pernah dialami peserta didik yang ada hubungannya dengan bahan yang akan diajarkan.

b) Kegiatan menggugah dan mengarahkan peserta didik dengan mengajukan pertanyaan, pendapat dan saran, menunjukkan gambar atau benda lain yang berhubungan dengan materi yang akan diajarkan.

2) Pelaksanaan proses belajar mengajar atau bagian inti.

a) Menjelaskan bahan pelajaran yang diikuti peragaan, demonstrasi, gambar, model bagan yang sesuai dengan keperluan.

b) Merumuskan hasil pengamatan dengan merinci, mengelompokkan atau mengklasifikasi materi pembelajaran yang diserap dari kegiatan pengamatan terhadap bahan pelajaran.

c) Menafsirkan hasil pengelompokkan itu dengan menunjukkan sifat, hal, dan peristiwa yang terkandung pada tiap-tiap kelompok.

d) Meramalkan sebab akibat kejadian prihal atau peristiwa lain yang mungkin terjadi di waktu lain atau mendapat suatu perluasan yang berbeda.

e) Menerapkan pengetahuan, keterampilan, sikap yang ditentukan atau diperoleh dari kegiatan sebelumnya pada keadaan atau peristiwa yang baru atau berbeda.

f) Merencanakan penelitian, dengan percobaan sehubungan masalah yang belum terselesaikan.

g) Mengkomunikasikan hasil kegiatan pada orang lain dengan diskusi, ceramah, mengarang dan lain-lain.

Berdasarkan permasalahan dan kelebihan pendekatan keterampilan proses tersebut, maka dalam artikel ini akan difokuskan untuk melihat kebergunaan pendekatan keterampilan proses dalam mereduksi permasalahan yang ada di kelas.

\section{METODE PENELITIAN}

Penelitian ini dilakukan untuk memperbaiki atau mereduksi permasalahan yang ada dikelas agar tujuan pembelajaran yang ingin dicapai lebih maksimal. Penelitian dilakukan 
dengan menggunakan metode siklus dilakukan dengan melalui empat penelitian tindakan kelas yang tahapan yakni perencanaan tindakan, mengikuti rancangan yang pelaksanaan tindakan, observasi dan dikembangkan oleh Kemmis, refleksi seperti yang ditunjukkan pada McTaggart, \& Nixon, (2014). Setiap Gambar 1.

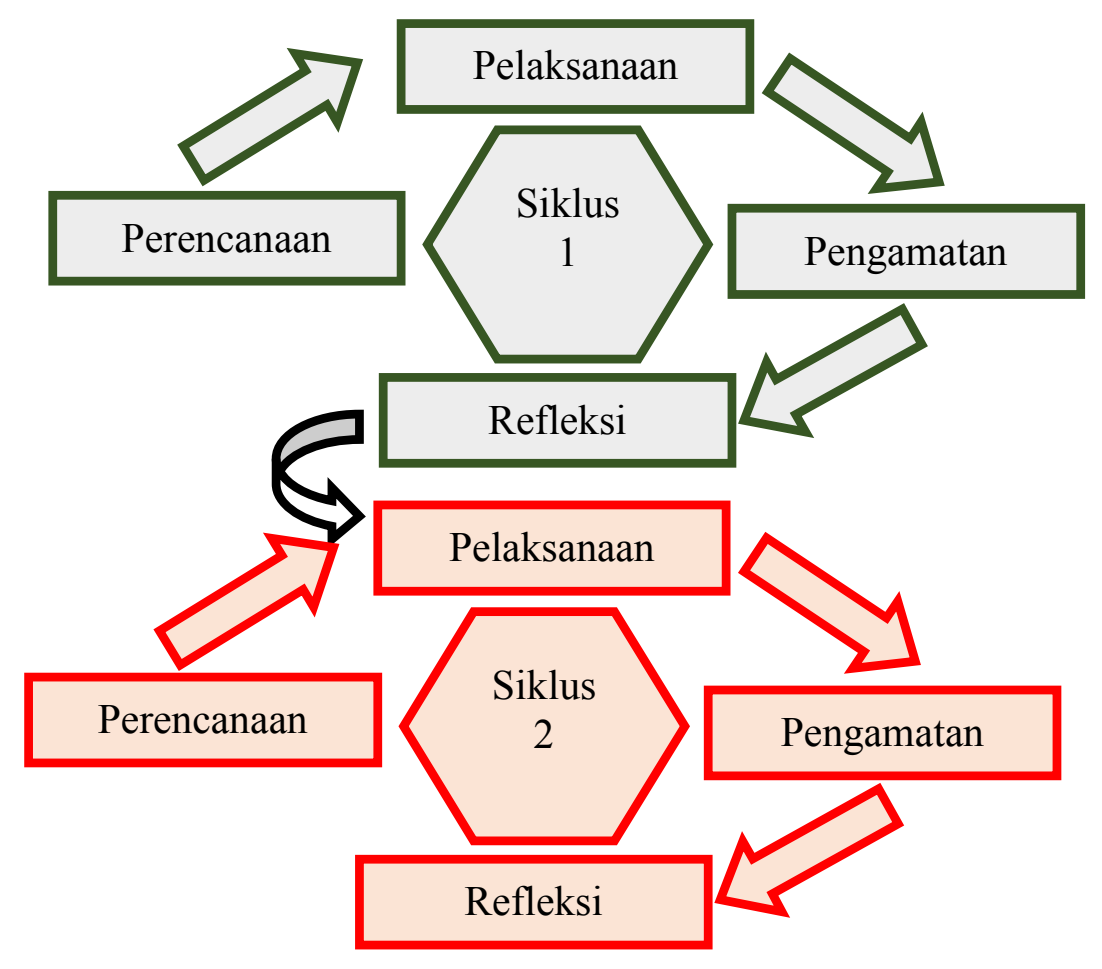

Gambar 1. Skema Pelaksanaan Tindakan

Penelitian dilakukan di SDN 004/V Kuala Tungkal, Kabupaten Tanjung Jabung Barat, Provinsi Jambi. Subjek penelitian terdiri dari 32 siswa kelas IV-B, yang terdiri dari 15 siswa laki-laki dan 17 siswa perempuan.

Berdasarkan permasalahan yang terjadi, penelitian ini difokuskan untuk mereduksi permasalahan yang ada dengan mengimplementasikan pendekatan keterampilan proses dalam pembelajaran konsep energi. Untuk melihat efektifitas upaya reduksi permasalahan tersebut maka diberikan 10 soal kepada siswa untuk masingmasing siklus. Soal tersebut telah memenuhi validitas konstruk dan validitas empirik serta reliabel berdasarkan uji coba yang telah dilakukan.

Data yang diperoleh dari
penelitian ini merupakan data kuantitatif dan kualitatif. Data kuantitatif diperoleh dari skor siswa dalam menjawab soal dan lembar observasi pembelajaran (dalam bentuk skor). Data kualitatif diperoleh dari lembar observasi keterlaksanaan pembelajaran (catatan-catatan temuan selama pembelajaran) dan wawancara.

Data kualitatif dianalisis dengan melakukan coding untuk pengelompokan dan penyederhanaan data. Hasil wawancara ditampilkan sesuai dengan hasil percakapan yang dilakukan ketika proses pengambilan data. Data kuantitatif dianalisis dengan 
menentukan skor siswa dalam skala 100 saat menjawab soal tes. Skor ditentukan dengan menggunakan persamaan:

$$
\text { Skor }=\frac{\text { Jumlah benar }}{\text { Jumlah soal }} \times 100
$$

Setelah ditentukan skor siswa, kemudian skor siswa tersebut dikelompokkan berdasarkan kriteria berikut (Asrini et al., 2016).

$$
\begin{array}{ll}
85 \leq \text { Skor } \leq 100 & \text { : sangat baik } \\
71 \leq \text { Skor } \leq 84 & \text { : baik } \\
65 \leq \text { Skor } \leq 70 & \text { : cukup } \\
41 \leq \text { Skor } \leq 64 & \text { : kurang } \\
0 \leq \text { Skor } \leq 40 & \text { : sangat kurang }
\end{array}
$$

\section{HASIL DAN PEMBAHASAN}

\section{Pelaksanaan Pembelajaran}

Penelitian ini menerapkan pembelajaran pendekatan keterampilan proses untuk meningkatkan pemahaman siswa pada materi energi. Pada hakikatnya pendekatan ini merupakan salah satu bentuk pengelolaan kegiatan pembelajaran yang difokuskan untuk mengupayakan agar siswa terlibat secara aktif selama proses pembelajaran (Semiawan, 1992).

Pelaksanaan pembelajaran di siklus I dan siklus II telah dilakukan sesuai dengan rencana yang telah dirancang dalam RPP. Pembelajaran yang dilakukan mengupayakan agar siswa memperoleh tujuh keterampilan proses yakni mengamati, mengklasifikasi, menafsirkan, meramalkan, menerapkan, merencanakan penelitian dan mengomunikasikan (Hikmawati, 2012).
Dalam pelaksanaan pembelajaran, siswa perlu dibiasakan untuk melakukan pembelajaran dengan pendekatan keterampilan proses. Hal ini perlu dilakukan karena siswa sebelumnya terbiasa belajar dengan hanya mendengarkan penjelasan guru. Sehingga ketika siswa diajarkan dengan menggunakan pendekatan keterampilan proses, siswa butuh beberapa penyesuaian. Dalam pelaksanaan penelitian, guru mengarahkan siswa dalam melakukan percobaan dan interpretasi hasil percobaan, meskipun percobaan yang dilakukan hanya sekedar mencari data kualitatif.

Kesulitan dalam menerapakan pendekaran keterampilan proses dalam pembelajaran ini lumrah terjadi. Kendati demikian, siswa tetap perlu dilatih untuk tidak sekedar diajar dengan menggunakan pembelajaran konvensional. Pembelajaran dengan menggunakan model konvensional memang cenderung lebih mudah dilaksanakan dan lebih cepat dalam menyelesaikan pembelajaran. Namun pembelajaran menjadi kurang bermakna (Haristy, Enawaty, \& Lestari, 2013; Panggabean, 2013). Siswa akan cenderung lebih sulit dalam menyimpan pemahaman mereka dalam long term memory sehingga akan lebih cepat lupa akan apa yang telah mereka pelajari.

\section{Skor Pemahaman Siswa}

Skor pemahaman siswa pada pokok bahasan energi meningkat dengan implementasi pendekatan keterampilan proses. Hal tersebut tampak dari perolehan skor siswa. Jumlah siswa berdasarkan perolehan skor untuk setiap siklus seperti yang ditunjukkan Gambar 2. 


\section{Masrah}

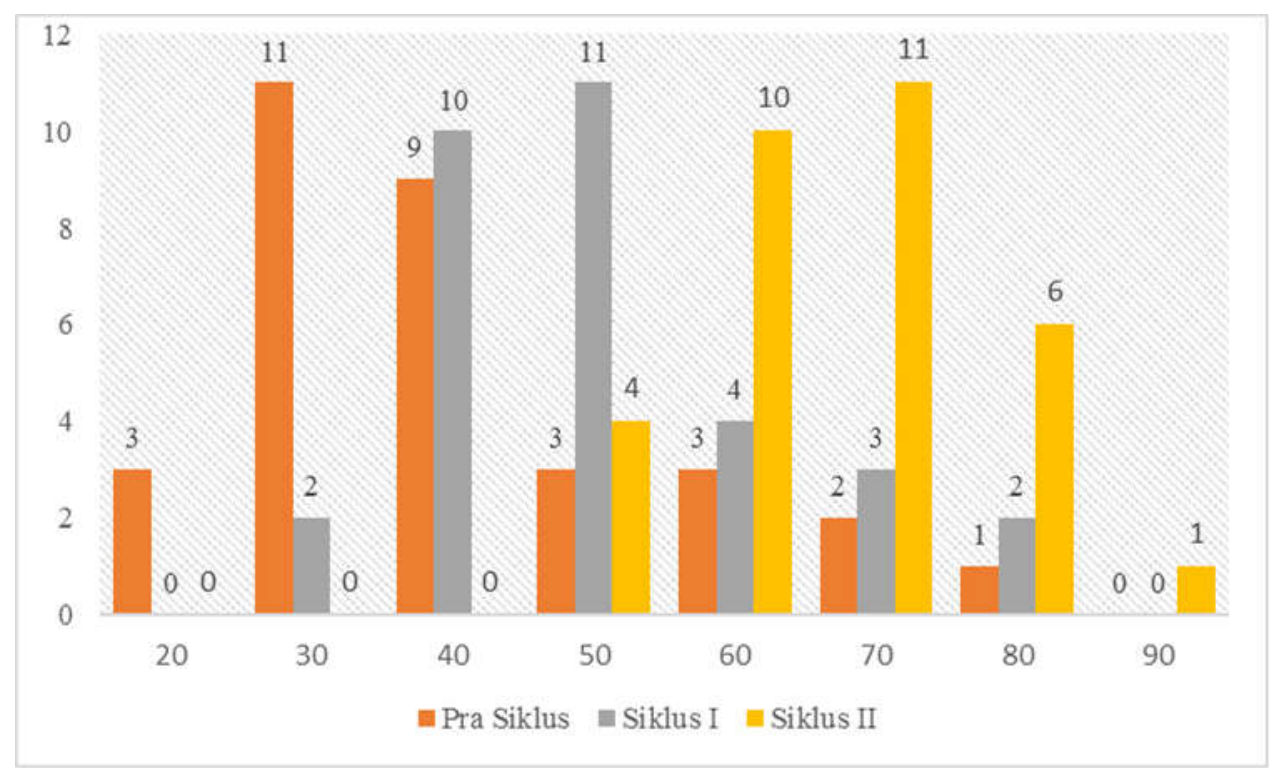

Gambar 2. Pengelompokan Siswa Berdasarkan Perolehan Skor Tes pada tiap Siklus.

Perubahan skor siswa mengindikasikan adanya peningkatan pemahaman siswa pada materi energi. Berdasarkan Gambar 2, jumlah siswa yang memperoleh skor 20 ada sebanyak 3 siswa kemudian pada siklus I dan II tidak ada siswa yang memperoleh skor 20. Berdasarkan data tersebut, rata-rata skor siswa mengalami peningkatan dari pra siklus ke siklus berikutnya. Pada pra siklus, rata-rata skor siswa adalah 40,63 kemudian meningkat menjadi 50,63 pada siklus I dan siklus II menjadi 66,88 .

Jika dilihat dari pengelompokan jumlah siswa berdasarkan kategori skor yakni sangat kurang, kurang, cukup, baik, dan sangat baik maka implementasi pembelajaran dengan menggunakan pendekatan keterampilan proses juga menunjukkan efektifitasnya. Berdasarkan Gambar 3 tampak bahwa skor siswa dengan kategori sangat kurang mengalami penurunan dari 23 siswa pada pra siklus menjadi 12 pada siklus I dan tidak ada siswa memperoleh skor sangat kurang pada siklus II. Sebanyak 6 siswa memperoleh skor pada kategiri kurang pada saat pra siklus kemudian menjadi 15 siswa pada siklus I dan turun menjadi 14 siswa pada siklus II. Untuk kategori cukup, jumlah siswa mengalami peningkatan pada tiap siklusnya, yakni 2 siswa pada pra siklus menjadi 3 siswa pada siklus I dan 11 siswa pada siklus II. Begitu pula skor siswa pada kategori baik, jumlah siswa juga selalu mengalami peningkatan yakni 1 siswa pada pra siklus menjadi 2 siswa pada siklus I dan 6 siswa pada siklus II. Terakhir, tidak ada siswa dengan skor kategori sangat baik pada pra siklus dan siklus I dan hanya 1 siswa memperoleh skor kategori sangat baik pada siklus II. 


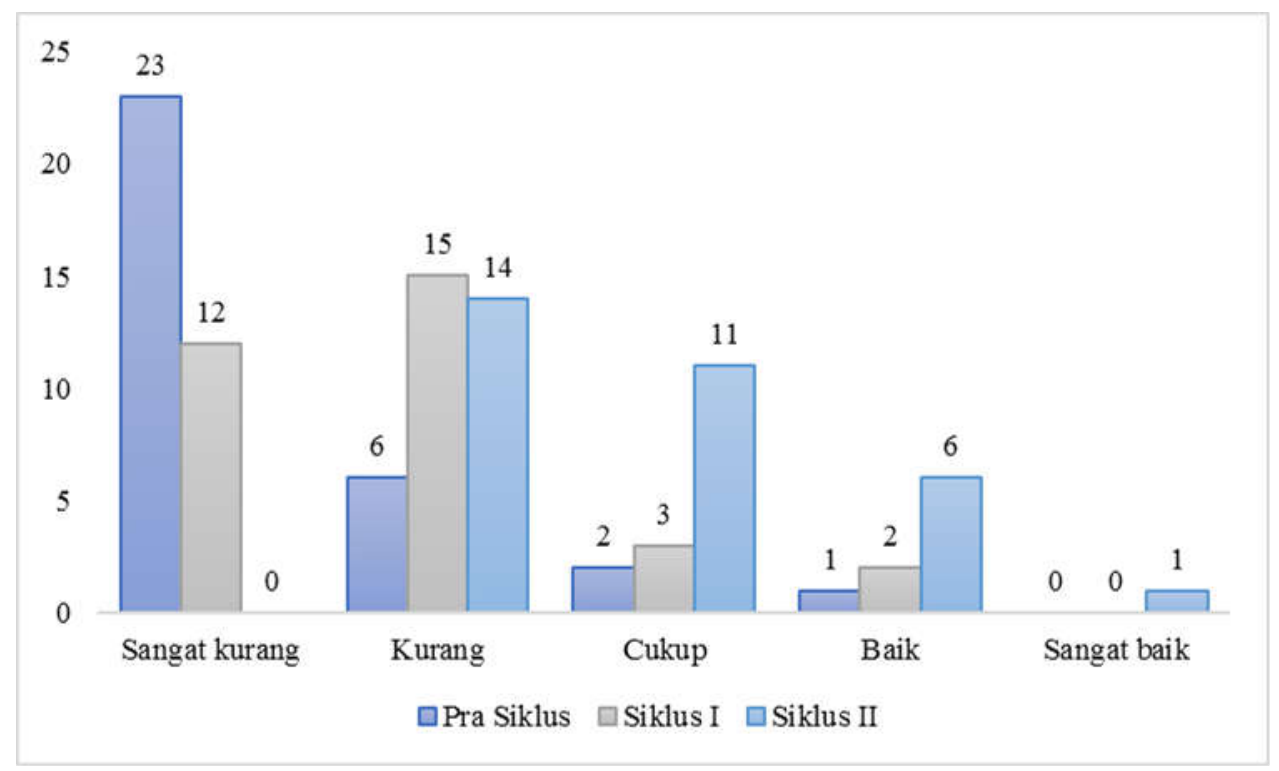

Gambar 3. Pengelompokan Jumlah Siswa Berdasarkan Kategori Skor

Berdasarkan wawancara yang dilakukan pada 5 siswa, seluruh siswa mengatakan bahwa pembelajaran yang dilakukan lebih menarik dari biasanya (pembelajaran konvensional). Siswa memberikan alasan bahwa pelajaran lebih menarik karena guru membaca alat peraga dalam menjelaskan konsep energi. Guru juga menyajikan gambargambar dan video yang berkaitan dengan energi. Selain itu, siswa merasa lebih senang jika pembelajaran dilakukan secara berkelompok.

Pembelajaran yang dilakukan dalam penelitian ini dilakukan secara sekuensial sedemikian rupa agar dapat mengonstruksi pemahaman siswa dengan baik. Pembelajaran secara sekuensial yang dilakukan melalui rekonstruksi pengetahuan pada siswa merupakan cara yang baik untuk membangun penguasaan konsep pada siswa (Viiri \& Savinainen, 2008). Untuk memenuhi tuntutan kurikulum, pendekatan keterampilan proses ini penting untuk diterapkan karena dapat meningkatkan hasil belajar siswa serta melibatkan siswa secara aktif dalam pembelajaran (Subagyo \& Marwoto, 2009). Dengan pendekatan keterampilan proses, siswa benar-benar dikondisikan untuk tidak hanya menerima pengetahuan dari apa yang disampaikan guru, namun berusaha membangun pengetahuan melalui bimbingan guru. Penggunaan pendekatan keterampilan proses ini membuat siswa belajar proses dan produk ilmu pengetahuan sekaligus. Sehingga, bagi guru yang terbiasa menggunakan pembelajara konvensional dengan metode ceramah dan mengalami kesulitan dalam menerapkan pendekatan-pendekatan yang mengarah pada proses saintifik adalah hal yang wajar. Namun perlu disadari bahwa pembelajaran demikian berguna bagi siswa dalam mengembangkan kognisi mereka.

Hasil tersebut sesuai dengan hasil penelitian Najiah (2019) bahwa pendekatan keterampilan proses dapat meningkatkan pemahaman konsep pada siswa Kelas VI SD inpres 5/81 Mallari, pencapaian pemahaman konsep energi bunyi pada siswa sudah sesuai yang diharapkan sebab telah memenuhi aspek tingkat penguasaan siswa dalam ketulusan belajar siswa. 
Hasil penelitian Acesta (2014) juga menjelaskan bahwa penerapan Pendekatan Keterampilan Proses dalam pembelajaran IPA tentang Konsep Gaya Magnet di kelas V SDN II Purwawinangun dapat meningkatkan hasil belajar siswa.

Peneliti pada dasarnya mengalami kesulitan dalam menggunakan pendekatan keterampilan proses dalam mengajarkan topik energi pada siswa. Hal tersebut dikarenakan siswa harus mendapatkan pengarahan dan perhatian selama proses pembelajaran. Banyak siswa yang bingung dengan apa yang harus dikerjakan. Kendati demikian, kesulitan tersebut tetap diupayakan untuk diatasi dengan perencanaan yang matang.

\section{SIMPULAN}

Penerapan

pendekatan

keterampilan proses berguna dalam meningkatkan pemahaman siswa mengenai konsep energi. Hal tersebut diindikasi dari peningkatan rata-rata skor tes siswa pada tiap siklusnya. Rata-rata skor siswa meningkat dari 40,63 pada pra siklus menjadi 50,63 pada siklus I dan 66,88 pada siklus II. Dalam perspektif guru, implementasi pendekatan keterampilan proses ini sebenarnya tidak mudah untuk dilaksanakan, karena siswa perlu benarbenar dibimbing selama proses pembelajaran. Namun demikian, dalam perspektif siswa, mereka justru senang dengan pendekatan keterampilan proses karena dinilai tidak membosankan.

\section{DAFTAR RUJUKAN}

Acesta, Arrofa. (2014). Penerapan Pendekatan Keterampilan Proses Sains untuk Meningkatkan Hasil Belajar Siswa dalam Pembelajaran IPA. Jurnal Ilmiah Pendidikan Dasar, 1(2), 96-106.
Agustinawati, N. (2014). Pengaruh Metode Pembelajaran dan Kemandirian Belajar Terhadap Hasil Belajar Sejarah Siswa di SMAN 7 Cirebon. Jurnal Pendidikan Sejarah. https://doi.org/10.21009/jps.032.0 1

Asrini, Ratman, \& Laganing, N. (2016). Meningkatkan Hasil Belajar Siswa Tentang Konsep Energi Bunyi Menggunakan Pendekatan Keterampilan Proses Di Kelas IV SDN 1 Siwalempu. Jurnal Kreatif Tadulako, 4(1), 251-267.

Docktor, J. L., Strand, N. E., Mestre, J. P., \& Ross, B. H. (2015). Conceptual problem solving in high school physics. Physical Review Special Topics - Physics Education Research, 11(2), 1-13. https://doi.org/10.1103/PhysRevS TPER.11.020106

Erowati, M. T. (2015). Pengaruh Penggunaan Media Benda Konkret Terhadap Hasil Belajar IPA Siswa Kelas IV di SDN Sumberejo 01. In Prosiding Seminar Nasional Pendidikan (p. 295). Surakarta: Universitas Sebelas Maret Surakarta dan ISPI Wilayah Jawa Tengah.

Haristy, D. R., Enawaty, E., \& Lestari, I. (2013). Pembelajaran Berbasis Literasi Sains pada Materi Larutan Elektrolit dan Non Elektrolit Di SMA Negeri 1 Pontianak. Jurnal Pendidikan Dan Pembelajaran, 2(12), 1-13. Retrieved from http://jurnal.untan.ac.id/index.php/ jpdpb/article/view/4002 
Hasan, H. (2017). Kendala Yang Dihadapi Guru Dalam Proses Belajar Mengajar Matematika Di SD Negeri Gani Kabupaten Aceh Besar. Jurnal Pesona Dasar, 1(4), 40-51.

Hikmawati. (2012). Penggunaan Pendekatan Keterampilan Proses dalam Meningkatkan Hasil Belajar Pesawat Sederhana Siswa di Kelas V SDN 51 Lambari. Jurnal Publikasi, 2(1), 44-53. https://doi.org/https://doi.org/10.2 6858/publikan.v2i1.1584

Husna, H., \& Pinem, K. (2011). Perbedaan Hasil Belajar Siswa Antara Pengajaran Multimedia Dengan Pengajaran Konvensional Pada Materi Iklim Global Di Kelas X Sma N 1 Seruway Kabupaten Aceh Tamiang T. Jurnal Geografi, 3(2), 83-93.

Kemmis, S., McTaggart, R., \& Nixon, R. (2014). The Action Research Planner_Doing Critica - Stephen Kemmis (Springer). New York.

Najiah.(2019).

Penggunaan

Pendekatam Keterampilan Proses Untuk Meningkatkan Pemahaman Siswa SD tentang Konsep Energi Bunyi. Dikdas Matappa: Jurnal Ilmu Pendidikan Dasar, 2(1), 7084.

Nuraisah, E., Irawati, R., \& Hanifah, N. (2016). Perbedaan Pengaruh Penggunaan Pembelajaran Konvensional Dan Pendekatan Kontekstual Terhadap Kemampuan Berpikir Kritis Matematis Dan Motivasi Belajar Siswa pada Materi Pecahan. Jurnal Pena Ilmiah, 1(1), 291300. https://doi.org/10.23819/pi.v1i1.30

33

Panggabean, D. (2013). Pemahaman Konsep Awal dan Kemampuan Berpikir Kritis Bidang Studi Fisika Menggunakan Model Pembelajaran Advance Organizer dan Model Pembelajaran .... Retrieved from http://digilib.unimed.ac.id/id/eprin t/3886

Rivaldo, L., Taqwa, M. R. A., \& Taurusi, T. (2018). Resources Siswa SMA tentang Konsep Gaya Archimedes. Jurnal Pendidikan Fisika Universitas Muhammadiyah Makassar, 6(3), 251-258.

https://doi.org/http://dx.doi.org/10. 26618/jpf.v6i3.1438

Roosyanti, Anna. (2017). Pengembangan Perangkat Pembelajaran Berorientasi Pendekatan Guided Discovery Untuk Melatihkan Keterampilan Berpikir Kritis dan Kreatif. Jurnal Pena Sains, 4(1), 60-73.

Ryan, Q. X., Frodermann, E., Heller, K., Hsu, L., \& Mason, A. (2016). Computer problem-solving coaches for introductory physics: Design and usability studies. Physical Review Physics Education Research, 12(1), 1-17.

Samatowa, U. (2006). Bagaimana membelajarkan IPA di sekolah dasar.

Saparwadi, L. (2016). Efektivitas Metode Pembelajaran Drill dengan Pendekatan Peer Teaching Ditinjau dari Minat dan Prestasi Belajar Matematika Siswa. Jurnal 
Didaktik Matematika, 3(1), 39-46. https://doi.org/10.24815/jdm.v3i1. 4304

Sayekti, I.C \& Kinasih, A.M., (2017). Kemampuan Guru Menerapkan Keterampilan Proses Sains dalam Pembelajaran IPA pada Siswa Sekolah Dasar. Jurnal Profesi Pendidikan Dasar. 4(1), 97-105.

Semiawan, C. (1989). Pendekatan Keterampilan Proses, Bagaimana Mengaktifkan Siswa Dalam Belajar. Jakarta: Gramedia.

Semiawan, C. (1992). Pendekatan Keterampilan Proses, Jakarta: PT.Gramedia.

Subagyo, Y., \& Marwoto, P. (2009). Pembelajaran Dengan Pendekatan Keterampilan Proses Sains Untuk Meningkatkan Penguasaan Konsep Suhu Dan Pemuaian. Jurnal Pendidikan Fisika Indonesia, 5(1), 42-46. https://doi.org/10.15294/jpfi.v5i1. 999

Taqwa, M. R. A., \& Faizah, R. (2016a). Konsepsi Mahasiswa pada Topik Kinematika. In Prosiding Seminar Nasional Pekan Ilmiah Fisika XXVII (pp. 96-101).

Taqwa, M. R. A., \& Faizah, R. (2016b). Perlunya Program Resitasi untuk Meningkatkan Kemampuan Mahasiswa dalam Memahami Konsep Gaya dan Gerak. Pros. Semnas Pend. IPA Pascasarjana UM, 12(1), 365-372.

Taqwa, M. R. A., \& Pilendia, D. (2018). Kekeliruan Memahami Konsep Gaya , Apakah Pasti Miskonsepsi? Jurnal Inovasi
Pendidikan Fisika Dan

Integrasinya, 01(02), 1-12.

Taqwa, M. R. A., \& Rivaldo, L. (2019).

Pembelajaran Problem Solving

Terintegrasi PhET: Membangun

Pemahaman Konsep Listrik

Dinamis. Kwangsan: Jurnal Teknologi Pendidikan, 07(01), 4556.

https://doi.org/http://dx.doi.org/10. 31800/jtp.kw.v7n1.p45--56

Viiri, J., \& Savinainen, A. (2008). Teaching-learning sequences: $A$ comparison of learning demand analysis and educational reconstruction. Am. J. Phys. Educ (Vol. 2). Retrieved from http://www.journal.lapen.org.mx 